[Cu eta' $\left.{ }_{2}\right],\left[\mathrm{Ni}\right.$ eta' eta $\mathrm{ClO}_{4},[$ Co eta' eta $] \mathrm{ClO}_{4},\left[\mathrm{CuL}_{2}\right]$ $\left(\mathrm{ClO}_{4}\right)_{2},\left[\mathrm{CuL}^{\prime} \mathrm{L}\right] \mathrm{ClO}_{4},\left[\mathrm{CuL}_{2}^{\prime}\right]$ 小うな式で示される構造を もった錯体と考えられるが，現在交での笑験結果だけからでは， これ以外のもっと複雑な構造をもつ可能性はないと断定すること はできない。ここに報告されたものは，すべて純粋な結晶として 単離できたものだけであるが，これ以外にも種々の軖体が溶液中 に存在しているようである。またニッケル(I)盐とエタノールア ミンを強アルカリ性アルコール溶液中で反応させると, 青色の浴 液となり，淟緗すると青他の絬晶性物質が得られたが，一定の組 成式を与之るような分析㢟はついに得られなかった。亜鉛（）に

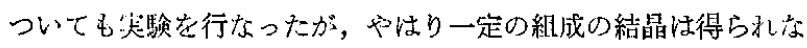
かった。 erythro 型の 1,2-ジフェニルエタノールアミンと銅(II)

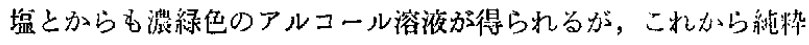
な結晶を得ることはいまだ成功していない。

銅 (I)錯体の可視部の吸収スベクトルを测徒した結果は, 衣 1 に示した。溶液中の鍇体注必ずしも結品状態と同じであるとはい えないが，少なくともこの衣から明らかなことは，M-OH-R か ら M-O-R となるにつれて, 关の可視部の吸収带が blue shift ッる傾向のあることである。
表 1 鍼(1)エタノールソミン捛よび 1,2-ジフェニルエ タノールアミン (threo 型) 鑤体のメタノール溶湤の四 収スペクトル

Cu eta' eta $\mathrm{ClO}_{4}$

Cu eta's

$\begin{array}{cc}\text { 吸収極大 }(\mathrm{m} \mu) & \text { 财光保数 } \\ 620 & 52.1 \\ 603 & 45.6 \\ 680 & 67.0 \\ 635 & 100 \\ 600 & 59.0\end{array}$

$\mathrm{CuL}_{2}\left(\mathrm{ClO}_{4}\right)_{2}$

$\mathrm{CuL}{ }^{\prime} \mathrm{L}\left(\mathrm{ClO}_{4}\right)$

$\mathrm{CuL}_{2}^{\prime}$

600

1,2-ジフェニルエタノールアミン銅(1)錯体の一つ $\mathrm{CuL}^{\prime} \mathrm{LClO}_{4}$ は緑色であるが，可視部の吸収極大の位置だけからは明らか比青 色となるべきである。これが緑色となったのは，近柴外部にある 级収带のすそが可視部にあらわれたためである。なぜこの錯体に だけこのような吸収が可視部にあらわれるか與味ある問題である が，現在まだ明らかにすることはできない。

終りに，本研究に協力された作岛好司，松本八重子，茂田文彦， 金谷伊佑の諸氏に感謝の意を表する。また貫重な試薬を提供して いただいた原田 整氏に心から感謝します。

(1962 年 11 月，錯塩化学討論会(一部)講演)

\title{
フラボノール-2'-スルホン酸によるトリウムの定
}

（昭和 39 年 2 月 28 日受理）

岡好 钴・山本勝 巳・青 木 正†

$0.1 \mathrm{~N} \sim p \mathrm{H} 2.0$ の酸性領域でトリウムとフラボノール-2'-スルホン酸が反応するとき組成 $1: 1$ のキレ一トを生し $365 \mathrm{~m} \mu$ を中

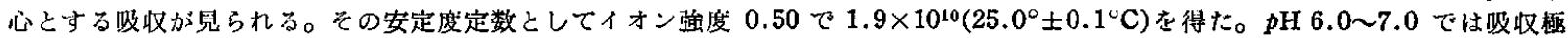

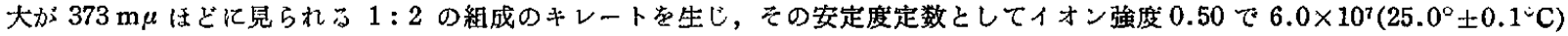
が得られた。フラボノールー2'-スルホン酸の熱力学的酸解隻定数として $6.0 \times 10^{-10}$ を得た。

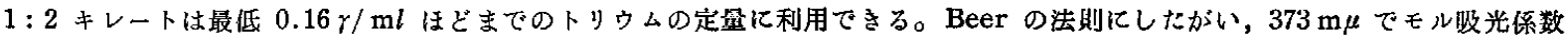
は 32700 で鋭䧶である。

\section{1 緒雱}

フラボノイドのうち三, 三のものはトリウムの定量に利用され ている。たとえばケルセチン1， あるいはこれをスルホン化した ケルセチンスルホン酸”，またはモーリン引は特定の $p \mathrm{H}$ で紬成 1:2のトリウムキレートを生じ，これを利用すれば微量のトリ ウムが定量される。藷者の研究室でケルセチンスルホン酸を伐っ た場合， $p \mathrm{H} 3.0$ 以下では 1:1 の組成のキレートを生じ， $p \mathrm{H}$ 5.0〜5.5 では 1:2のキレートを生ずることを明らかにし，定量 に利用2した。しかし，反応し得る 3 簓所の官能基群のうちどこ で反纪しているか，またその安定度定数はどのくらいのものであ るが知ることができなかった。それで 3，4 位に水酸基とカル ボニル基だけを持っているフラボノールを使ってこれを明らかに すると同時に，トリウムの定量に利用するさいの基礎的条件を検 討した。なおフラボノールは水に溶けにくいので $2^{\prime}$ 位にスルホ

†東北大学理学部化学教帘, 仙台洧片平丁

1) O. Menis, D. L. Manning, G. Goldstein, Anal.Chem. 21, 1426 (1957).

2) 管野, 分析化学 9, 319(1960)

3) M. H. Fletcher, R. G. Milky, Anal. Chem. 28, 1402(1956).
ン酸基を入れて水溶性4として用いた。

な扮酸解離定数および安定度造数を求める場合はフラボノイド と各種の金属イオンの反応性を比較する資料を得ることを目的と したので，イオン強度を一定にしたほか $p H$ メーターで得られた $p \mathrm{H}$ 值をそのまま水素イオン濃度として計算した。

\section{2 実験および結果}

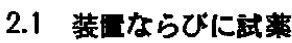

财光度の測定には日立製分光光度計 EPU-2A 型および自記式 EPS-2 型を， $p \mathrm{H}$ の測定には日立製 EHP-2 型ガラス電極 $p \mathrm{H}$ メーターを用いた。安定度定数掞よび酸解離定数を求めるときに はセル室の温度を $25.0^{\circ} \pm 0.1^{\circ} \mathrm{C}$ にたった。

試薬としてはフラボノール-2'-スルホン酸のナトリウム塩》を 用い,トリウム塩としては硝酸トリウムを使った。

\section{2 .フラボノール-2'ースルホン酸の酸解唯定数}

試薬の酸解離定数についてはずで当研究宝でイオン強度 0.30 で求められているせが, さらに $0.10,0.50,1.00$ のイオン強度 において酸解離定数を測定し, それらの值から熱力学的酸解離是

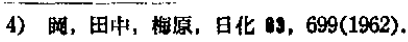


数を求めた。イオン強度は過䜖素酸ナトリウムを用いて調整し， 酸解離定数を求めるさい汢既報》と同棁に报った。

試薬の溇度を $8.40 \times 10^{-5} \mathrm{~mol} / l$ と一定にしておき， $p \mathrm{H}$ を 8 ふら9の範囲で変化して各波長におけ当吸光庑定測定し，

$$
\frac{a}{\left(A-A_{0}\right)}=\frac{1}{\left(\varepsilon-\varepsilon_{0}\right)}+\frac{1}{\left(\varepsilon-\varepsilon_{0}\right) K_{a}}\left[\mathrm{H}^{+}\right]
$$

にしたがって $a /\left(A-A_{0}\right)$ と [H+] との関係を求めると図 1〜3 に示したような直線関係が得られた。ただし(1)式において $a$ は

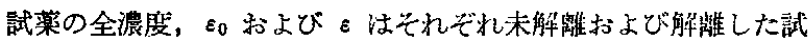
楽のモル吸光倸数， $A$ は測定波長での全吸光庭， $A_{0}$ は $\varepsilon_{0} a ， K_{a}$

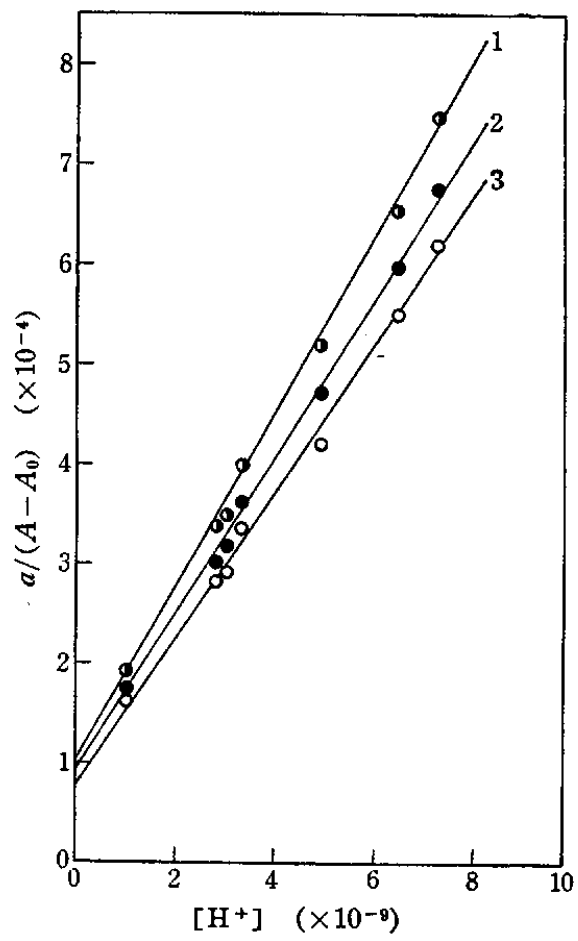

1: $395 \mathrm{~m} \mu, 2: 390 \mathrm{~m} \mu, 3: 380 \mathrm{~m} \mu$ フラボノール-2'-スルホン酸ナトリウム： $8.40 \times 10^{-5} \mathrm{~mol} / l$ $p \mathrm{H}=8.14 \sim 8.99,25.0^{\circ} \pm 0.1^{\circ} \mathrm{C}, \mu=0.10$

図 $1 a /\left(A-A_{0}\right)$ と $\left[\mathrm{H}^{+}\right]$との関係

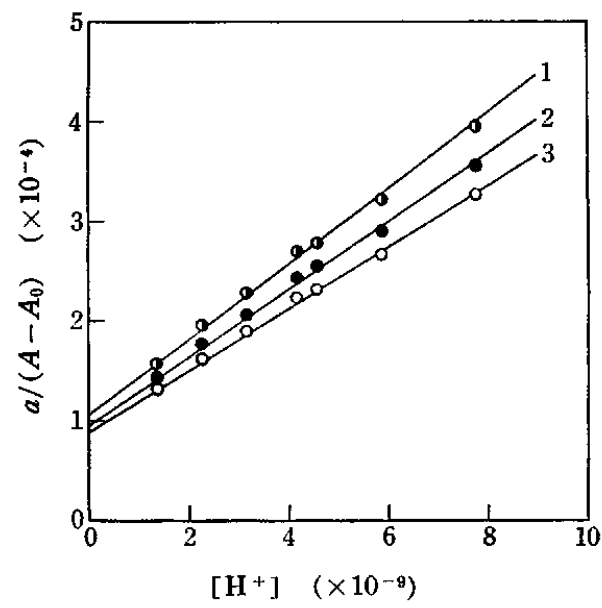

1: $395 \mathrm{~m} \mu, 2: 390 \mathrm{~m} \mu, 3: 380 \mathrm{~m} \mu$ フラボノール-2'-スルホン酸ナトリウム： $8.40 \times 10^{-5} \mathrm{~mol} / l$ $p \mathrm{H}=8.11 \sim 8.86,25.0^{\circ} \pm 0.1^{\circ} \mathrm{C}, \mu=0.50$

図 $2 a /\left(A-A_{0}\right)$ と $\left[\mathrm{H}^{+}\right]$との関係
は酸解踓定数とした。表 1 は図 1〜3に示した結果から統計的に 回帰式を求㱛て得た酸解碓定数である。また四 4 にイオン強度 $(\mu)$ と得られた酸解離定数 $\left(p K_{a}\right)$ との関䋆定示した。図に見られ るように $\mu^{1 / 2}$ と $p K_{a}$ との間には直線関係が得られ， $\mu=0$ に拈 ける $p K_{a}$ の值として 9.2，Ka として $6.0 \times 10^{-10}$ が得られた。

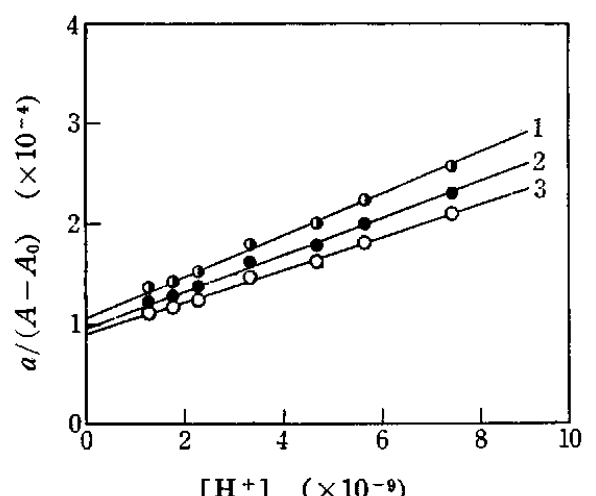

1: $395 \mathrm{~m} \mu$, 2: $390 \mathrm{~m} \mu$, 3: $380 \mathrm{~m} \mu$ フラボノール-2'ースルホン酸ナトリウム： $8.40 \times 10^{-5} \mathrm{~mol} / l$ $p \mathrm{H}=8.13 \sim 8.89,25.0^{\circ} \pm 0.1^{\circ} \mathrm{C}, \mu=1.00$

図 $3 a /\left(A-A_{0}\right)$ と $\left[\mathrm{H}^{+}\right]$との関係

表 1 フラボノール-2'-スルホン酸の酸解離定数

\begin{tabular}{|c|c|c|c|c|}
\hline & & & ${ }_{2}(\times 10$ & \\
\hline$\mu$ & & 0.10 & 0.50 & 1.00 \\
\hline & 380 & 1.1 & 3.1 & 5.5 \\
\hline 波長 $(\mathrm{m} \mu)$ & $\{390$ & 1.0 & 3.1 & 5.5 \\
\hline & $(395$ & 1.3 & 3.0 & 5.4 \\
\hline 均 & 値 & 1.2 & 3.1 & 5.5 \\
\hline$p K_{a}$ & & 8.9 & 8.5 & 8.3 \\
\hline
\end{tabular}

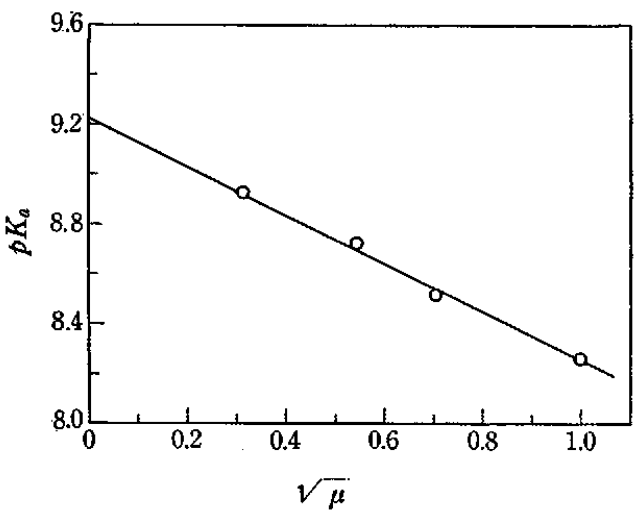

図 4 イオン強度と酸解離定数との関俰

\section{3 トリウムーフラポノール-2'-スルホン酸キレートの吸収曲} 線

フラボノール-2'-スルホン酸の䟴度を $8.40 \times 10^{-4} \mathrm{~mol} / l$, ト リウムの浱度を $2.09 \times 10^{-5} \mathrm{~mol} / l$ と一定にしておき， $p \mathrm{H}$ を变 化させたときに生成するキレートの吸収曲線を图 5 にあげた。対 照溶液としては同一濃度の試薬溶液它用いた。なお $350 \mathrm{~m} \mu$ 以下 では試薬の吸収が強くて測定が困難であったので $355 \mathrm{~m} \mu$ 以上て 測定した。

曲線 I は $0.1 \mathrm{~N}$ の硝酸酸性で得られたキレートの吸収曲楾で, 曲線IおよびI注それぞれ $p \mathrm{H}$ を 1.5，2.0にしたときの吸収曲 線である。図から見られるようにキレートは $365 \mathrm{~m} \mu$ を中心とす 
る吸収帶を示し, $p \mathrm{H} 2.0$ 以下゙では溶液の酸性:度を変化させても吸

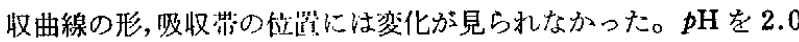

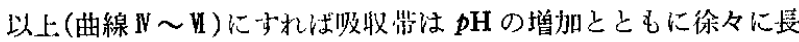

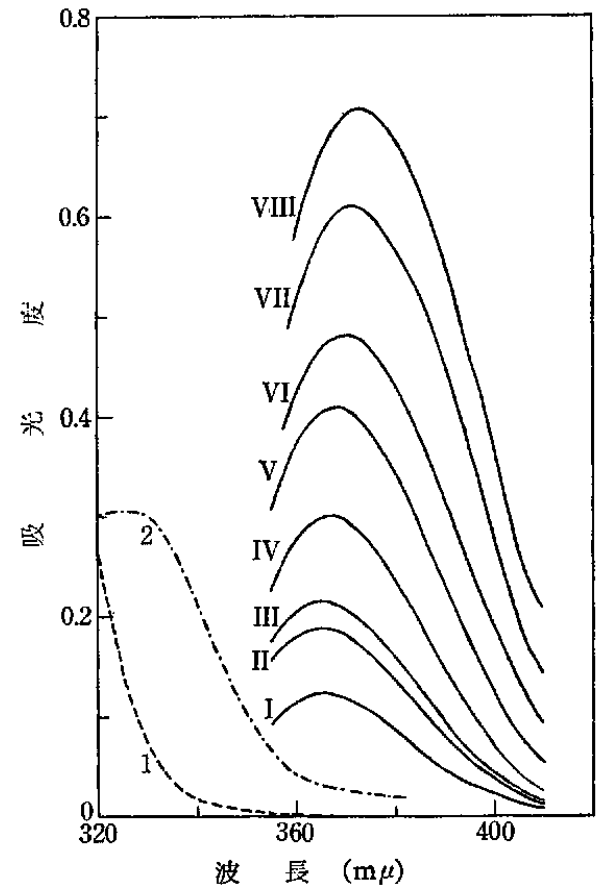

硝酸トリウム: $2.09 \times 10^{-5} \mathrm{~mol} / l$

フラポノールー2'ースルホン酸ナトリウム: $8.40 \times 10^{-4} \mathrm{~mol} / \mathrm{l}$

I : $\mathrm{HNO}_{3} 0.1 \mathrm{~N}, \quad$ il $p \mathrm{H} 1.5, \quad$ I : $p \mathrm{H} 2.0$,

V : $p \mathrm{H} 3.0, \quad \mathrm{~V}:$ pH 4.0, V: $p \mathrm{H} 5.0$,

VI: $p \mathrm{H} 6.0, \quad$ VII: $p \mathrm{H} 7.0$

1: 硝酸トリウム $1.67 \times 10^{-3} \mathrm{~mol} / l(p \mathrm{H}=1.2)$

2: フラボノール-2'-スルホン酸ナトリウム $3.34 \times 10^{-5} \mathrm{~mol} / l(p \mathrm{H}=6.5)$

図 5 トリウムーフラボノールー2'ースルホン酸系 吸取曲線の $\mathrm{pH}$ による贸化

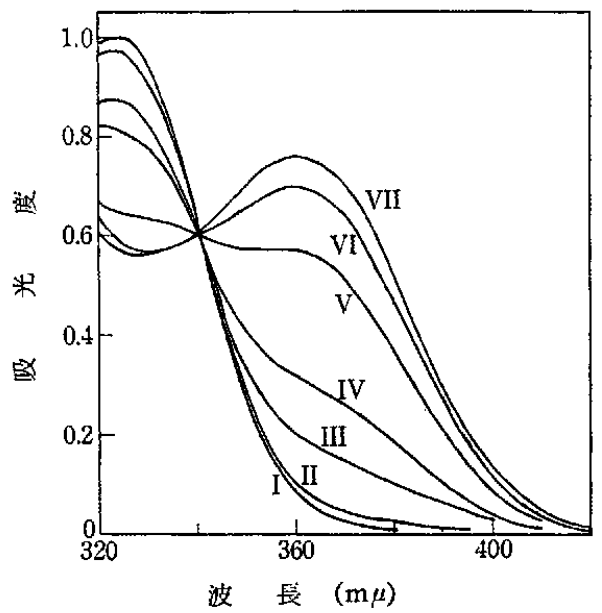

フラボノールー2'ースルホン酸: $8.48 \times 10^{-5} \mathrm{~mol} / l, p \mathrm{H}=1.8$ 硝酸トリウム $(\mathrm{mol} / \mathrm{l})$ 一

I : $0, \quad \mathbb{I}: 4.18 \times 10^{-6}, \quad$ I : $2.09 \times 10^{-5}$,

VI: $4.18 \times 10^{-5}$, V: $8.36 \times 10^{-5}$, VI $1.67 \times 10^{-4}$,

II: $4.18 \times 10^{-4}$

図 6 トリウムーフラボノール-2'-スルホン酸 湝合溶液の股光度

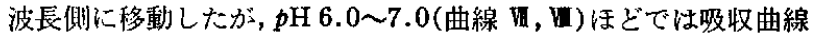

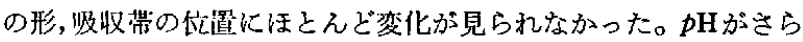
に増すと解離した形の試薬の吸光度が增し測定が困難であった。

上に述べたように硝酸 $0.1 \mathrm{~N}$ ないし $p \mathrm{H} 2.0$ で生成するキレー

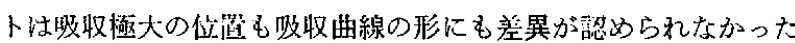
ので，この酸性度範进では 1 耗類のキレートが生ずるものと考え られ，pH を 6.0〜7.0にした場合性他の 1 種類のキレートを生 ずるものと考学られる。中間の $p H$ 2.0 6.0 の範囲では軕者が 共存しているむのと思われる。

なお曲線 $1 ， 2$ にそれぞれ $1.67 \times 10^{-8} \mathrm{~mol} / l$ の硝酸トリウム， および $3.34 \times 10^{-5} \mathrm{~mol} / l$ の武㴪の吸収曲線を示した。

\section{$2.4 p H 2.0$ 以下で生成するキレート}

上に述べたように $p \mathrm{H} 2.0$ 以下゙では試渠が過剩に存在しても 1

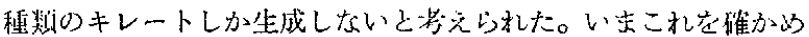
るため $p \mathrm{H}$ 穵 1.8 , 試梁の濃度宛 $8.48 \times 10^{-5} \mathrm{~mol} / l$ と一定にし “拈き，トリウムの浱作老 $4.18 \times 10^{-6} \mathrm{~mol} / l$ 汃ら $4.18 \times 10^{-4}$ $\mathrm{mol} / l$ まで湾化して吸光度の变化を汢かったところ図 6 にあげ た結果它得た。曲線 I は試莩だけの忣收曲線である。図から見ら れるように各曲線は $340 \mathrm{~m} \mu$ でまじわり， $p \mathrm{H} 1.8$ では試薬が過 剩に存枉しても，またトリウムが過剩に存在しても生成するキレ 一トは1種数であることが加った。ゆえにつぎに $p \mathrm{H} 2.0$ 以下 で生成するキレートの組成を確かめた。

2.4.1 トリウムが遇制に存在する场合：トリウムが試薬と(2) 式にしたがって反伈与るものとすると平衡定数 $K_{1}$ は，

$\mathrm{Th}^{4+}+n \mathrm{HFS} \rightleftarrows \mathrm{Th}(\mathrm{FS}){ }_{n}^{(4-n)}+n \mathrm{H}^{+}$

$$
K_{1}=\frac{\left[\mathrm{Th}(\mathrm{FS}) n^{(4-n)}\right]\left[\mathrm{H}^{+}\right]^{n}}{\left[\mathrm{Th}^{4+}\right][\mathrm{HFS}]^{n}}
$$

となる。

ただし HFS でフラボノール-2'-スルホン酸をあらわした。い まトリウムイオンの初搌度を $a \mathrm{~mol} / l$, 試萊のそれを $b \mathrm{~mol} / l$, 生成したキレートの溦愿它 $x \mathrm{~mol} / l$ と与をと,

$$
K_{1}^{\prime}=\frac{K_{1}}{\left[\mathrm{H}^{+}\right]^{n}}=\frac{x}{(a-x)(b-n x)^{n}}
$$

またある波長における溶液の全改光度を $A$ とすれば,

$$
A=\varepsilon_{1} x+\varepsilon_{\mathrm{L}}(b-n x)+\varepsilon_{\mathrm{M}}(a-x)
$$

ただし $\varepsilon_{1} ， \varepsilon_{\mathrm{L}} ， \varepsilon_{\mathrm{M}}$ 注それぞれ生じたキレート，試薬，ならびに トリウムのその波長におけるモル没光係数とした。このさいトリ ウムが通剩に估佂与れば低次のキレートが生じやすいと考えられ る。それで(2)式において $n=1$ と仮定して跣報ら)と同椂に取り 扱えば(5)式が得られる。

$$
\begin{array}{r}
\frac{b}{\left(A-A_{\mathrm{L}}-A_{\mathrm{M}}\right)}=\frac{1}{\left(\varepsilon_{1}-\varepsilon_{\mathrm{L}}-\varepsilon_{\mathrm{M}}\right)} \\
\quad+\frac{1}{\left(\varepsilon_{1}-\varepsilon_{\mathrm{L}}-\varepsilon_{\mathrm{M}}\right)} \cdot \frac{1}{K_{1}{ }^{\prime}} \cdot \frac{1}{a}
\end{array}
$$

ただし $\varepsilon_{\mathrm{L}} b=A_{\mathrm{L}}, \varepsilon_{\mathrm{M}} a=A_{\mathrm{M}}$ とした。

いま過塩素酸を用いて酸性度を $0.22 \mathrm{~N}$, 試薬の濃度を 4.18 $\times 10^{-5} \mathrm{~mol} / \mathrm{l}$ と一定にしておき，トリウムの浱度を $6.56 \times 10^{-4}$ $\mathrm{mol} / l$ から $4.10 \times 10^{-3} \mathrm{~mol} / l$ に变化して前と同様な取り扱い5

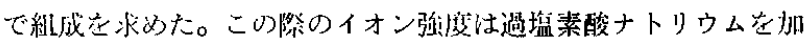
えて 0.50 にたもった。 $b /\left(A-A_{\mathrm{L}}-A_{\mathrm{M}}\right)$ と $1 / a$ の関倸を求める と図 7 に示したような直線関係が得られた。すなわち生成するキ レートは 1:1 であることを示している。

5) 睞, 田中, 日化 81, 1846(1960). 


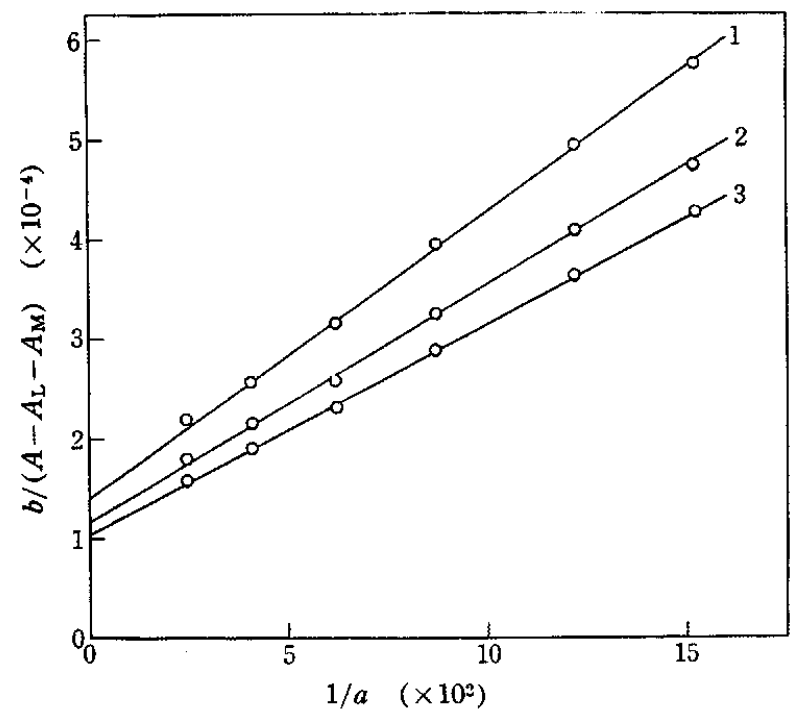

1: $380 \mathrm{~m} \mu$, 2: $375 \mathrm{~m} \mu$, 3: $370 \mathrm{~m} \mu$ フラポノールー2'ースルホン酸ナトリウム: $4.18 \times 10^{-5} \mathrm{~mol} / \mathrm{l}$ 硝酸トリウム： $6.56 \times 10^{-4} \sim 4.10 \times 10^{-3} \mathrm{~mol} / l$ $\mathrm{HClO}_{4}: 0.22 \mathrm{~N}, \mu=0.50\left(\mathrm{NaClO}_{4}\right), 25.0^{\circ} \pm 0.1^{\circ} \mathrm{C}$ 図 $7 b /\left(A-A_{\mathrm{L}}-A_{\mathrm{M}}\right)$ と $1 / a$ との関係

表 2 平衡定数 $\left(K_{1}\right)$

\begin{tabular}{|c|c|c|c|}
\hline 波長 $(\mathrm{m} \mu)$ & 回 䙊 式 & $K_{1}^{\prime}\left(\times 10^{2}\right)$ & $K_{1}(\times 10)$ \\
\hline 370 & $\begin{array}{c}b /\left(A-A_{\mathrm{L}}-A_{\mathrm{M}}\right)=1.0_{6} \times 10^{-4} \\
+2.0_{9} \times 10^{-7} \cdot 1 / a\end{array}$ & 5.1 & 5.9 \\
\hline 375 & $\begin{array}{c}b /\left(A-A_{\mathrm{L}}-A_{\mathrm{M}}\right)=1.1_{\mathrm{g}} \times 10^{-4} \\
+2.3_{2} \times 10^{-7} \cdot 1 / a\end{array}$ & 5.1 & 6.0 \\
\hline 380 & $\begin{array}{c}b /\left(A-A_{\mathrm{L}}-A_{\mathrm{M}}\right)=1.4_{5} \times 10^{-4} \\
\quad+2.8_{3} \times 10^{-7} \cdot 1 / a\end{array}$ & 5.1 & 6.0 \\
\hline 平 & 值 & 5.1 & 6.0 \\
\hline
\end{tabular}

以上の結果から 1:1 キレートについての平衡定数を求めた。 (5)式にしたがって図 7 の各波長における闪齊式および平衡定数 を求めると表 2 に示声とおりであった。

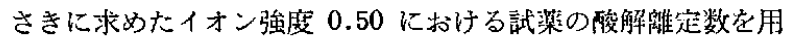

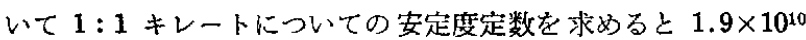
の值が得られた。

2.4 .2 試薬が䢰制に存在する坦合： $p \mathrm{H}$ 穵 1.60 , トリウムの 濃度を $2.09 \times 10^{-5} \mathrm{~mol} / l$, 試粱の濃度を $1.34 \times 10^{-3} \mathrm{~mol} / l$ 加 ら $3.34 \times 10^{-3} \mathrm{~mol} / l$ と種々に変化した場合についても，前と同 様(5にて組成を求めた。この際のイオン強度は過塭絜酸ナトリ ウムを加えて 0.10 にたもった。図 5 の曲線 1 から見られるよう に，用いたトリウム濃度では利用した測定波長で得られる吸光度 は全吸光度に対して小であり無視して差し支えない。それゆえ (5)式を求めたと同様にして(6)式が導かれる。

$$
\frac{a}{\left(A-A_{\mathrm{L}}\right)}=\frac{1}{\left(\varepsilon_{1}-n \varepsilon_{\mathrm{L}}\right)}+\frac{1}{\left(\varepsilon_{1}-n \varepsilon_{\mathrm{L}}\right)} \cdot \frac{1}{K_{1}{ }^{\prime}} \cdot \frac{1}{b^{n}}
$$

い主 $\left(A-A_{\mathrm{L}}\right)$ を測定し $a /\left(A-A_{\mathrm{L}}\right)$ と $1 / b^{n}$ との関係を求める と図 8 に示したような結果が得方れた。四 8 の实線は $n=1$ とし た場含で，破線は $n=2$ 上した場全である。少なわた， $n=1$ とし

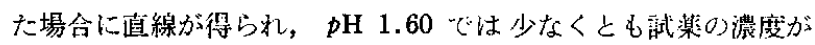
$3.34 \times 10^{-3} \mathrm{~mol} / l$ までは $1: 1$ の䋖成のキレートが生成するこ とが知られた。

以上の結果から $1: 1$ キレートについての平衡定数を水めた。

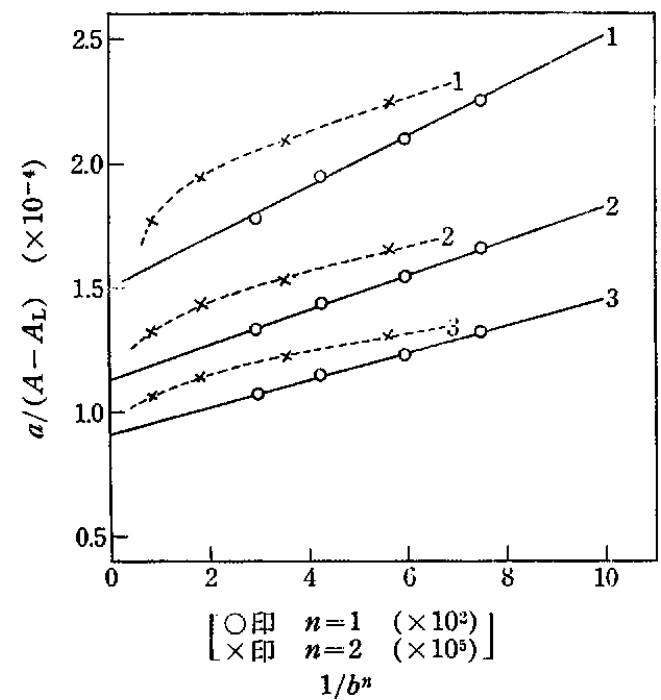

1: $390 \mathrm{~m} \mu, 2: 385 \mathrm{~m} \mu$, 3: $380 \mathrm{~m} \mu$

硝酸トリウム: $2.09 \times 10^{-5} \mathrm{~mol} / l$

フラボノール-2'ースルホン酸ナトリウム:

$1.34 \times 10^{-3} \sim 3.34 \times 10^{-3} \mathrm{~mol} / l$

$p \mathrm{H}=1.60, \mu=0.10\left(\mathrm{NaClO}_{4}\right), 25.0^{\circ} \pm 0.1^{\circ} \mathrm{C}$

圀 $8 a /\left(A-A_{\mathrm{L}}\right)$ と $1 / b^{n}$ との関係

表 3 平衡定数 $\left(K_{1}\right)$

\begin{tabular}{|c|c|c|c|}
\hline 波長 $(\mathbf{m} \mu)$ & 回＼cjkstart班＼cjkstart式 & $K_{1}^{\prime}\left(\times 10^{3}\right)$ & $K_{1}(\times 10)$ \\
\hline 380 & $\begin{array}{c}a /\left(A-A_{1}\right)=0.91_{3} \times 10^{-4} \\
+5.3_{2} \times 10^{-8} .1 / b\end{array}$ & 1.7 & 4.2 \\
\hline 385 & $\begin{array}{c}a /\left(A-A_{\mathrm{L}}\right)=1.1_{2} \times 10^{-4} \\
+7.1_{9} \times 10^{-8} \cdot 1 / b\end{array}$ & 1.6 & 3.8 \\
\hline 390 & $\begin{array}{c}a /\left(A-A_{\mathrm{L}}\right)=1.4_{8} \times 10^{-4} \\
+10.2_{7} \times 10^{-8} \cdot 1 / b\end{array}$ & 1.4 & 3.5 \\
\hline 平 & 值 & 1.6 & 3.8 \\
\hline
\end{tabular}

(6)式にしたがって図 8 の各波言における回㴆式および平衡定数 を求めると表 3 に示宁と打りであった。

さらにイオン強度 0.10 に拈ける陚薬の酸解離定数を用いて $1: 1$ キレートについての安定度定数を求めると $3.4 \times 10^{10}$ の值 が得られた。イオン強度が異なり，トリウムが過剩をたは試薬が 過剩と実験条件は異なるが，1:1 キレートについてほぼ一致し た安定度定数が得られた。

\section{$2.5 p H 7.0$ 付近で生成するキレート}

さきに述べたように $p \mathrm{H} 2.0$ 以上においては $1: 1$ のキレー トのほがもう一つの高次のキレートが共存するものと考えられ る。そこで 1:1 のキレートがつぎ式,

$$
\begin{aligned}
& \mathrm{Th}(\mathrm{FS})^{3+}+(n-1) \mathrm{HFS} \\
& \rightleftarrows \mathrm{Th}(\mathrm{FS})_{n^{4-n}+(n-1) \mathrm{H}^{+}}
\end{aligned}
$$

にしたがって高次のキレートを生成すると平衡定数 $K_{2}$ は，

$$
K_{2}=\frac{\left[\mathrm{Th}(\mathrm{FS}) n_{n}^{(4-n)}\right]\left[\mathrm{H}^{+}\right]^{(n-1)}}{\left[\mathrm{Th}(\mathrm{FS})^{3+}\right]\left[\mathrm{HFS}^{(n-1)}\right.}
$$

で示され，ある波長に打的る全吸光度 $A$ は,

$$
A=\varepsilon_{1} x+\varepsilon_{2} y+\varepsilon_{\mathrm{L}}(b-x-n y)+\varepsilon_{\mathrm{M}}(a-x-y)
$$

で亦される。ただし $x, y$ はそれぞれ $1: 1$ および $1: n$ の組成

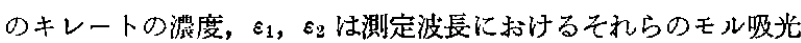
係数とした。

実験にあたってはトりウム熄の浱度は $2.09 \times 10^{-5} \mathrm{~mol} / l$ と一 定にし, 試楽の浱度は $8.40 \times 10^{-4} \mathrm{~mol} / l$ 加 $2.31 \times 10^{-3} \mathrm{~mol} / l$ 


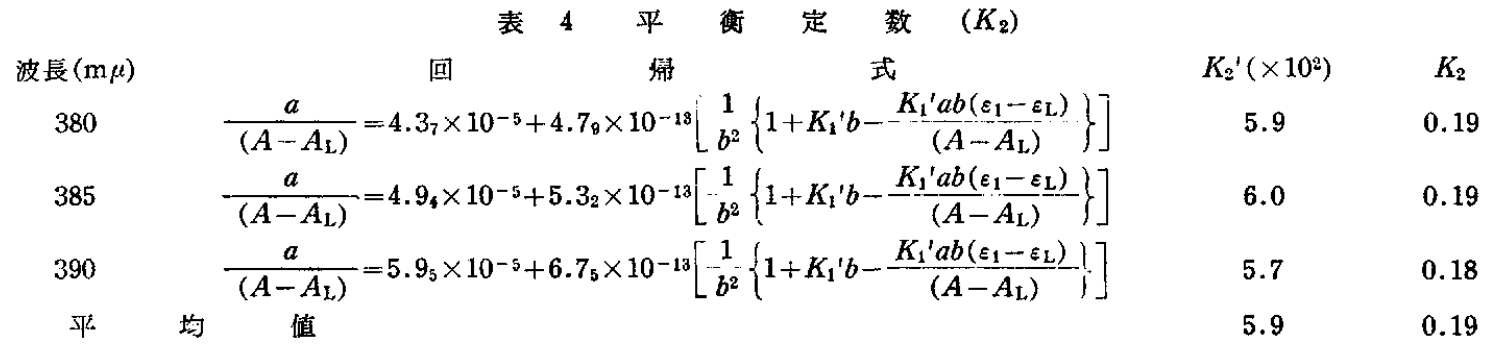

と種々に変化し， $p \mathrm{H}$ は 3.50 とした。なおイオン強度は過塩索 酸ナトリウム它加说「 0.50 亿調節した。図 5 の曲線 1 から見れ ば，このさいトリウム堛の吸収の全吸光度に対声る寄与は小さ く，舆視して差し支えない。乙たがって式(10)が導かれる。

$$
\begin{aligned}
& \frac{a}{\left(A-A_{\mathrm{L}}\right)}=\frac{1}{\left(\varepsilon_{2}-n \varepsilon_{\mathrm{L}}\right)}+\frac{1}{K_{\mathrm{1}}{ }^{\prime} K_{2}^{\prime}\left(\varepsilon_{2}-n \varepsilon_{\mathrm{L}}\right)} \cdot \frac{1}{b^{n}} \\
& \quad \times\left\{1+K_{\mathrm{l}}^{\prime} b-\frac{K_{1}^{\prime} a b\left(\varepsilon_{1}-\varepsilon_{\mathrm{L}}\right)}{\left(A-A_{\mathrm{L}}\right)}\right\}
\end{aligned}
$$

ただし $K_{2}{ }^{\prime}=\frac{K_{2}}{\left[\mathrm{H}^{+}\right]^{(n-1)}}$ とした。いま $n$ に種々な值を与え, $a /\left(A-A_{\mathrm{L}}\right) と \underset{b^{n}}{1}\left\{1+K_{1}^{\prime} b-\frac{K_{1}^{\prime} a b\left(\varepsilon_{1}-\varepsilon_{\mathrm{L}}\right)}{\left(A-A_{\mathrm{L}}\right)}\right\}$ との間に直線関倸 が得られるような $n$ の值を選べば，それは $1: 1$ キレートと共存 するキレートの縕成を示すことになる。 $380,385,390 \mathrm{~m} \mu$ の各 波長においてこれ定試みると因 9 の結果を得た。四から明らかな ように $n=2$ とすれ代各波長で直線が得られるが， $n=3$ とした 場合に㩐曲する。したがって上の条件で生成するキレートの組 成は $1: 2$ と判定される。

(10)式の関係を示した図9の各波長における直線の回帰式を求 め，それから $K_{2}^{\prime}$ および平衡定数 $K_{2}$ を求め表 4 に示した。

$1: 1$ キレートの場合と同様にその安定度定数を求めると 6.0 $\times 10^{7}(\mu=0.50)$ 染得られた。

\section{6 トリウムの濃度と吸光度}

图5に見られるように $1: 2$ キレートは 1:1 キレートにくら

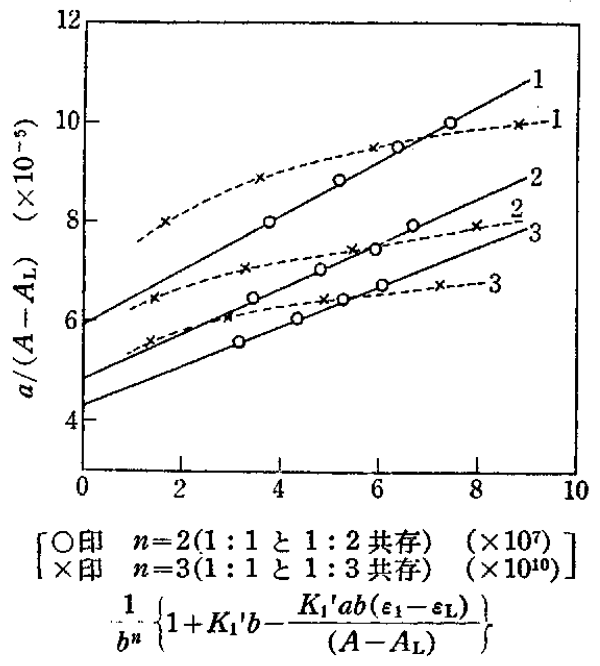

1: $390 \mathrm{~m} \mu, 2: 385 \mathrm{~m} \mu, 3: 380 \mathrm{~m} \mu$ 硝酸トリウム: $2.09 \times 10^{-5} \mathrm{~mol} / l$ フラボノール -2 -スルホン酸ナトリウム: $8.40 \times 10^{-4} \sim 2.31 \times 10^{-3} \mathrm{~mol} / l$ $p \mathrm{H}=3.50, \mu=0.50\left(\mathrm{NaClO}_{4}\right), 25.0^{\circ} \pm 0.1^{\circ} \mathrm{C}$ 园 $9 a /\left(A-A_{\mathrm{L}}\right)$ と $\frac{1}{b^{n}}\left\{1+K_{1}{ }^{\prime} b-\frac{K_{1}{ }^{\prime} a b\left(\varepsilon_{\mathrm{L}}-\varepsilon_{\mathrm{L}}\right)}{\left(A-A_{\mathrm{L}}\right)}\right\}$ との関係

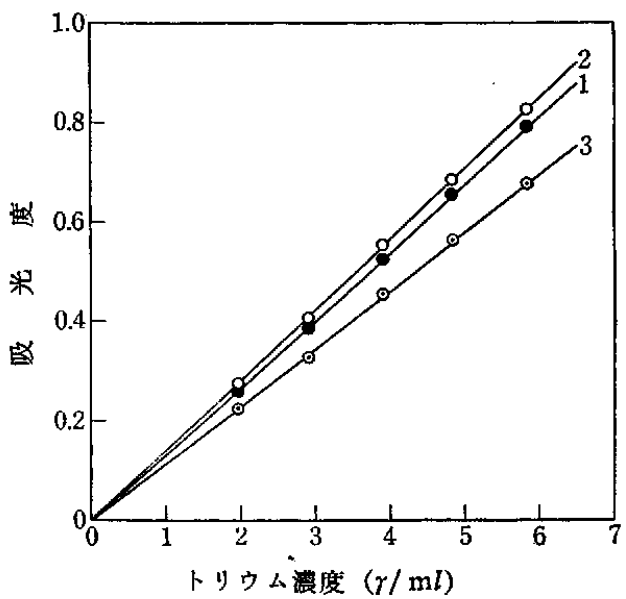

1: $380 \mathrm{~m} \mu, 2: 373 \mathrm{~m} \mu, 3: 360 \mathrm{~m} \mu$ フラポノールー2'ースルホン酸ナトリウム: $8.40 \times 10^{-4} \mathrm{~mol} / l, p \mathrm{H}=7.00$

図 10 検 量 線

ベてモル吸光係数が大きくトリウムの定量に用い得れば有利であ る。また同様な吸収曲線の形および吸收带の位置が pH 6〜7で 見られるので,ささに得られた平衡定数を用いキレートの生成量 を求めた。試澨の濃度を $8.40 \times 10^{-4} \mathrm{~mol} / l$, トリウムの濃度を $8.36 \times 10^{-6} \mathrm{~mol} / \mathrm{l}$ とし, $p \mathrm{H} 7.0$ において, $1: 2$ キレートの生 成量を求めると採取したトリウム量の $99.9 \%$ に相当し，キレー トの生成はほとんど芯了していることがわかった。

そこで試楽の濃度を $8.40 \times 10^{-4} \mathrm{~mol} / l$ とし，トリウムの溇度 を $8.36 \times 10^{-6} \mathrm{~mol} / l$ から $2.51 \times 10^{-5} \mathrm{~mol} / l$ まで変化させ, pH 7.0 において 360,373 および $380 \mathrm{~m} \mu$ の各波長で吸光度を 求めると図 10 の検量線が得られた。ただし対照液としては同一 濃度の試薬溶液を使用した。検量線はいずれも原点を通る苴線と なり Beer の法則にしたがうことを示している。 $373 \mathrm{~m} \mu$ にお けるモル吸光係数は 32700 で，これはトリン法旬(モル吸光係数 16600) およびネオトロン法りにくらべ約 2 倍鋭敏でヶル七チン 法1)(モル吸光係数 33000)，ケルセチンスルホン酸法2)(モル吸光 係数 33100) と大略等しい鋭敏度を有し,トリウムの定量に有利に 利用し得ることがわかった。

本研究に使用した EPS-2 型日立自記分光光度計は東洋レーヨ ン科学技術研究助成金で睡入したものである。同社に厚く惑謝す る。尔扣研究費の一部は文部省科学研究費によった。あわせて謝 意を表する。

（1961 年 4 月，日本化学会第 14 年会； 1962 年 7 月，日本分析 化学会第 11 年会講演）

6) P. F. Thomason, M. A. Perry, W. M. Byerly, Anal. Chem. 21, 1239(1949).

7) 石摴, 東, 分析化学 4，14(1955). 